\title{
Human hyoid bones from the middle Pleistocene site of the Sima de los Huesos (Sierra de Atapuerca, Spain)
}

\author{
I. Martínez $^{\text {a,b,*, }}$ J.L. Arsuaga ${ }^{\text {b,c }}$, R. Quam ${ }^{\text {b,d }}$, J.M. Carretero ${ }^{\text {bee }}$, \\ A. Gracia ${ }^{\text {b }}$ L. Rodríguez ${ }^{\mathrm{e}}$ \\ a Área de Paleontología, Departamento de Geología, Universidad de Alcalá de Henares, \\ Edificio de Ciencias, Campus Universitario, 28871 Alcalá de Henares, Spain \\ ${ }^{\mathrm{b}}$ Centro de Investigación (UCM-ISCIII) sobre, Evolución y Comportamiento Humanos, c/Sinesio Delgado, 4, 28029 Madrid, Spain \\ ${ }^{\mathrm{c}}$ Departamento de Paleontología, Facultad de Ciencias Geológicas, Universidad Complutense de Madrid, Ciudad Universitaria s/n, 28040 Madrid, Spain \\ ' Department of Anthropology, American Museum of Natural History, Central Park West at 79th Street, New York, NY 10024-5192, USA \\ ${ }^{\mathrm{e}}$ Departamento de Ciencias Históricas y Geografía, Universidad de Burgos, Facultad de Humanidades y Educación, 09001 Burgos, Spain
}

\begin{abstract}
This study describes and compares two hyoid bones from the middle Pleistocene site of the Sima de los Huesos in the Sierra de Atapuerca (Spain). The Atapuerca SH hyoids are humanlike in both their morphology and dimensions, and they clearly differ from the hyoid bones of chimpanzees and Australopithecus afarensis. Their comparison with the Neandertal specimens Kebara 2 and SDR-034 makes it possible to begin to approach the question of temporal variation and sexual dimorphism in this bone in fossil humans. The results presented here show that the degree of metric and anatomical variation in the fossil sample was similar in magnitude and kind to living humans. Modern hyoid morphology was present by at least 530 kya and appears to represent a shared derived feature of the modern human and Neandertal evolutionary lineages inherited from their last common ancestor.
\end{abstract}

Keywords: Atapuerca; Homo heidelbergensis; Hyoid bone; Middle Pleistocene; Sima de los Huesos

\section{Introduction}

The hyoid bone is one of the least represented skeletal elements in the human fossil record, and the recent discovery of an Australopithecus afarensis hyoid bone (Alemseged et al., 2006), reported as being chimpanzee-like, has generated renewed interest in the evolutionary significance of this bone in the human lineage. Previously, only two hyoids from the genus Homo were known: the Kebara 2 Neandertal specimen (Arensburg et al., 1989, 1990; Arensburg, 1991) and the Neandertal hyoid body
SDR-034 (Rodríguez et al., 2003) from the site of El Sidrón cave (Asturias, Spain), dated to around $43 \mathrm{ka}$ (Rosas et al., 2006).

Both Neandertal specimens are modern-human-like in size and shape (Arensburg et al., 1989; Rodríguez et al., 2003). Based on the Kebara 2 hyoid, it was proposed that the position, form, size, and relationship of this bone with the Neandertal larynx was also modern-human-like and that, consequently, these fossil humans had the capacity for spoken language (Arensburg et al., 1989, 1990). Other researchers have contested this conclusion, arguing that neither the dimensions nor the morphology of the hyoid bone were direct indicators of the position of the larynx in the throat (Lieberman et al., 1992). On the other hand, the chimpanzeelike bulla-shaped hyoid bone of $A$. afarensis has been suggested to be consistent with the presence of laryngeal air sacs in this hominin species 
(Alemseged et al., 2006), a primitive feature of apes including chimpanzees but not present in modern humans (Aiellø and Dean, 1990; Nishimura et al., 2006).

The chimpanzee-like anat my of the hyøid appears to represent the primitive hominin condition, and its presence in $A$ afarensis indicates that the derived modern human morphol- gy emerge at søme point during the course of human evølutionary history. The presence of a human-like hyoid in the Neandertal specimens Kebara 2 and SDR-034 suggests that this derive condition was als present in the last commøn ancestor of the Neandertal and modern human evelutionary lineages. In this context, the twø human hyøid bones recovered frøm the middle Pleist $\bullet$ cene site $\bullet$ the Sima de løs Huesøs in the Sierra de Atapuerca in northern Spain are particularly relevant, because they considerably extend the known fossil record for the genus Homo to deep in the middle Pleistocene and can help elucidate when the derived hyøid morphølogy first emerged in the human lineage.

\section{Materials and methods}

The Sierra de Atapuerca is well known for both the extraordinarily large sample of middle Pleistocene human fossils recovered from the site of the Sima de los Huesos (Arsuaga et al., 1993; Arsuaga et al., 1997a) and for the discovery of some of the •ldest human fossils in Eurøpe in the lower Pleistocene beds of the Gran Dølina site (Carbønell et al., 1995; Bermúdez de Castrø et al., 1997). The Sima de los Huesos (SH) site is at the foot of a 13-m-deep shaft placed deep inside a cave (Cueva Mayor) located on the southern slope of the Sierra de Atapuerca. Prior to the 2006 field season, the SH site has yielded more than 5,500 human fossils, belonging to at least 28 individuals (Bermúdez de Castr et al., 2004), which have been assigned to the species Homo heidelbergensis and are considered to represent the ancestral European population that evelved int the Neandertals (Arsuaga et al., 1997b; Martínez and Arsuaga, 1997). The $\mathrm{SH}$ site has a firm minimum radiometric age

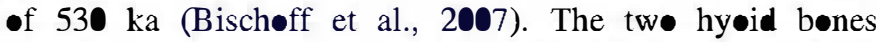
described here were recovered in 1994 (AT-1500) and 1997 (AT-2000).

T• compare the main metric dimensions of the SH fossils, we have relied on a mixed-sex sample of modern humans in the Hamann-Tødd Osteøløical Collection housed at the Cleveland Museum of Natural History (USA). This sample consists of 60 individuals, 34 African-Americans (22 males and 12 females) and 26 European-Americans (23 males and 3 females). This sample size is equivalent th that used by Arensburg et al. (1989), but it shøws less tempøral heter geneity and a lower degree of variation. We have als relied on a small sample of 17 modern human hy॰id bones for the morphølogical comparisons. Seven of these derive from cadaveric dissection of male individuals at the School of Medicine at the Universidad Autonøma in Madrid, and the remaining ten, of unknown sex, were recovered during systematic excavations -f a medieval Spanish cemetery from the San Pabl• monastery in Burgøs, Spain (Adán-Álvarez, 2003). We have alsø had the -pportunity t• study the original hyøid of Kebara 2, høused in the Department of Anatømy and Anthrøp $\bullet$ gy at Tel Aviv University. The main metric dimensions and anatomical details of the hyoid body SDR-034 have been published previ-usly (Rodríguez et al., 2003). We have measured the same variables in the tw॰ $\mathrm{SH}$ individuals and the modern human sample as those defined previously by Arensburg et al. (1989) (Table 1).

\section{The Atapuerca (SH) hyoid bones}

\section{$A T-1500$}

This specimen is a nearly complete hyøid bødy that shows -nly slight loss of the external table of bone, particularly in the region of the anterior tubercle and in the area of articulation between the body and the right greater horn (Fig. 1). However, most of the articular surfaces between the body and the greater horns are preserved, and their presence implies that the greater horns had not yet fused to the body. The superior and the inferior borders are completely preserved, and the bødy shows a modern-human-like profile in lateral view that is clearly different from the bulla shape found in chimpanzees or the DIK-1-1 specimen.

In ventral view, the hyøid bødy has a subquadrangular shape, with the transverse (mediølateral) width being greatest at the level of the superior border. The ventral aspect has a very strong anterior tubercle on the midline. On

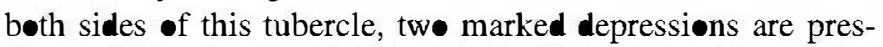
ent in the region of the insertion of the geniøhyoid muscles. The ventral surface does not extend to any great degree below the anterior tubercle. The dorsal aspect does not have the bulla shape characteristic of chimpanzees; rather, it is smo•thly concave, similar t• modern human hyøids. Nevertheless, a moderate and well-delimited circular depression søme $8 \mathrm{~mm}$ in diameter is present in the center of the dorsal aspect. Finally, the superior border has a V-shaped contour in superior view.

Table 1

Measurement definitions for the hyoid body

Measurement Definition

Maximum medial height

Maximum distance from the upper to the lower borders of the body along the sagittal plane.

Maximum wansverse diameter Maximum diameter of the body taken in the transverse (ML) plane.

Anteroposterior thickness Direct distance between a line joining the upper and the lower posterior margins of the body at the midline, and the most prowuding anteromedial point on the ventral aspect.

Depth of the posterior surface Measured from a line joining the upper and the lower posterior margins of the body in the sagittal plane to the most anteromedial point on the dorsal aspect.

Thickness of the inferior border Measured in the sagittal plane of the inferior border. 


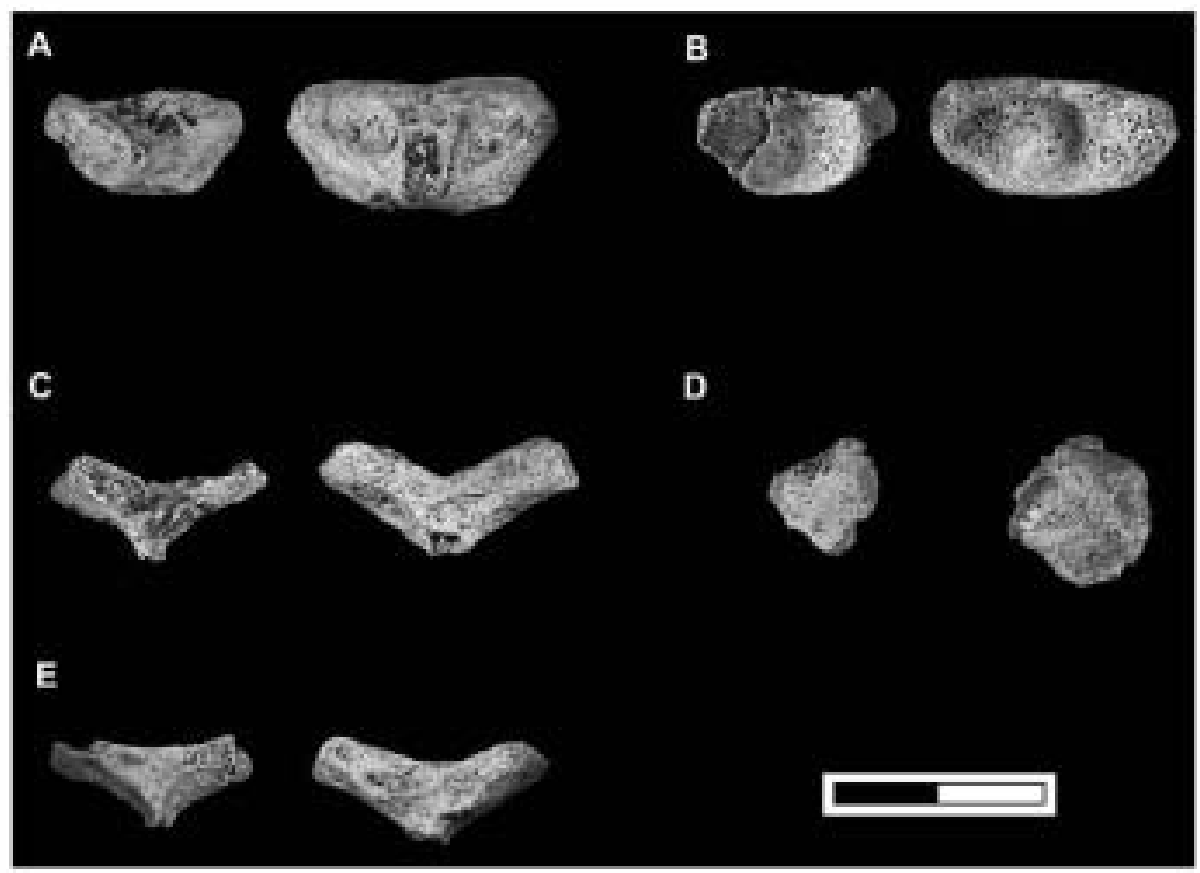

Fig. 1. The AT-2000 (left) and AT-1500 (right) Sima de los Huesos hyoid bones in venwal (A), dorsal (B), superior (C), lateral (left side) (D), and inferior views (E). Scale bar $=2 \mathrm{~cm}$.

\section{$A T-2000$}

This specimen consists of most $\bullet$ a hyøid bødy characterized by more extensive loss of the external table than in AT-1500, mainly in the left portion of the dorsal aspect, along the superior border, and in the right region of the ventral aspect next to the articulation with the greater horns (Fig. 1). In spite of this ersiøn, part or most of the articular surface with the greater horns is preserved on both sides, suggesting, as in the case of AT-1500, that the greater horns had not yet fused to the body. In addition, the presence of the articular surfaces for the greater horns indicates that the slight erosion present along the superior border did not significantly alter the original size and shape of the body. As in AT-1500, the lateral profile is modern-human-like.

The bødy $\bullet$ AT-2000 has a subquadrangular shape in ventral view, with the transverse width along the superior border being greater than that along the inferior border. A marked anterior tubercle - smaller than that in AT-1500-is visible

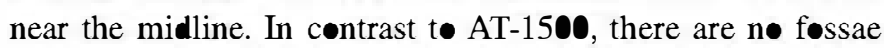
on either side of the tubercle for the insertion of the geniøhyoid muscles in AT-2000. In the better preserved left lateral portion of the ventral aspect, below the anterior tubercle, three small fossae can be distinguished at the insertion sites for the

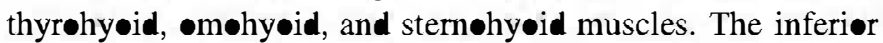
border of AT-2000 is completely preserved along its midline and is somewhat thinner than that of AT- 1500 .

The dorsal aspect of AT-2000 is not bulla-like, but is regularly concave, as is the case in AT-1500. However, there is no well-delimited circular depression as in AT-1500. In superior view, the contour of AT-2000 is more open, or horseshøeshaped, than in AT-1500, and it does not show the marked apex that characterizes the V-shape in AT-1500.
Age at death

The main criterion for approaching the age at death based on the hyoid bone in living human populations is the state of fusion of the greater horns with the body ('Halloran and Lundy, 1987; Miller et al., 1998; Shimizu et al., 2005). However, there is a large degree of variation, and very late fusion or even nonfusion in elderly individuals is commonly encountered ('Halloran and Lundy, 1987; Miller et al., 1998). Thus, it is not possible to estimate the age at death in the individuals represented by AT-1500 and AT-2000 based on the lack of fusion of the greater horns with the hyoid body.

At the same time, the $\bullet$ ssification $\bullet$ f the hyoid bødy begins very shortly after birth in living human populations (Reed, 1993) and progresses throughøut infancy and adolescence as the dimensions of the hyoid body increase. The value for the maximum medial height appreaches $10 \mathrm{~mm}(9.7 \pm 2.4 \mathrm{~mm})$ at around 15 years of age (Reed, 1993). The value in adult individuals in this same variable was found to be only slightly higher $(11.7 \pm 1.6 \mathrm{~mm})$ in the present study. Importantly, the value for the maximum medial height in the adult Neandertal specimen Kebara $2(13.4 \mathrm{~mm})$ is 1.06 standard deviations (SD) abøve øur adult modern human pøøled-sex sample mean and 0.78 SD abøve our adult male mean (Table 2), suggesting that adult Neandertals reached similar values in the maximum medial height as do adult modern humans. This similarity in adult dimensions between modern humans and Kebara 2 suggests a late-adolescent or adult age status for both of the SH hyøid bødies, the maximum medial heights $\bullet$ which are easily encompassed within the adult modern human range of variation in the present study. 
Table 2

Measurements $(\mathrm{mm})$ and comparisons of the AT- 1500 and AT-2000 hyoid bones

\begin{tabular}{|c|c|c|c|c|c|}
\hline Specimen/sample & $\begin{array}{c}\text { Maximum } \\
\text { medial height }\end{array}$ & $\begin{array}{l}\text { Maximum transverse } \\
\text { diameter }\end{array}$ & $\begin{array}{l}\text { Anteroposterior } \\
\text { thickness }\end{array}$ & $\begin{array}{c}\text { Depth of posterior } \\
\text { surface }\end{array}$ & $\begin{array}{c}\text { Thickness of } \\
\text { the inferior border }\end{array}$ \\
\hline Atapuerca AT-1500 & 10.8 & 21.8 & 6.8 & 2.8 & 1.7 \\
\hline Atapuerca AT-2000 & 10.2 & 18.6 & 6.7 & 1.6 & 1.3 \\
\hline Kebara 2 & $13.4^{1}$ & $24.6^{1}$ & $5.8^{1}$ & $3.8^{1}$ & $1.3^{2}$ \\
\hline SDR-1 $34^{2}$ & 10.5 & - & 5.5 & 2.6 & 1.7 \\
\hline \multicolumn{6}{|c|}{ Modern humans (pooled sex; $n=6 \mathbf{0}$ ) } \\
\hline Mean $\pm S D$ & $11.7 \pm 1.6$ & $22.3 \pm 2.7$ & $8.6 \pm 1.3$ & $1.9 \pm .7$ & \\
\hline Range & $7.9-15.7$ & $16.6-30.6$ & $5.4-11.1$ & $\bullet .6-3.9$ & \\
\hline \multicolumn{6}{|c|}{ Modern human males $(n=45)$} \\
\hline Mean \pm SD & $12.3 \pm 1.4$ & $23.2 \pm 2.2$ & $8.9 \pm 1.1$ & $2.1 \pm .7$ & \\
\hline Range & $8.9-15.7$ & $18.6-30.6$ & $6.9-11.1$ & e.6-3.9 & \\
\hline \multicolumn{6}{|c|}{ Modern human females $(n=15)$} \\
\hline Mean \pm s.d. & $10.1 \pm 1$. & $19.6 \pm 2.3$ & $7.8 \pm 1.6$ & $1.5 \pm .5$ & \\
\hline Range & $7.9-11.5$ & $16.6-24.2$ & $5.4-11$. & e.9-2.6 & \\
\hline
\end{tabular}

${ }^{1}$ Data are from Arensburg et al. (1989).

${ }^{2}$ Data are from Rodríguez et al. (2003).

\section{Comparative morphological analysis}

The anatomical descriptions of the SH hyøids clearly demonstrate that they are human-like in their morphology, and direct comparison between the SH specimens and the Neandertal specimens Kebara 2 and SDR-034 (Rødríguez et al., 2003) reveals some interesting details. All four specimens show a strong anterior tubercle. The fossae for the insertion of the geniøhyoid muscles on either side of the midline are deeper and more defined in the Kebara 2 specimen than in AT-1500, and they are absent on AT-2000. The right and left lateral portions $\bullet$ the ventral surface, below the anterior tubercle, on Kebara 2 show fossae for the insertion of the $\bullet$ mohy muscle (Arensburg et al., 1989). These are absent in AT-1500, while AT-2000 shows three smaller fossae inferiorly on either

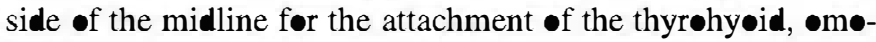
hyøid, and sternohyøid muscles. At the same time, SDR-034

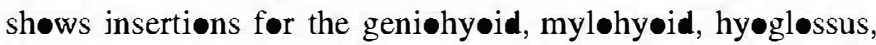
digastric, and styløhyøid muscles (Rødríguez et al., 2003). The dorsal aspect of AT-1500 shows a smeoth concavity marked by a well-defined circular depression. This depression is absent in AT-2000 and the SDR-034 (Rødríguez et al., 2003) and Kebara 2 Neandertals, demonstrating søme degree of variation in the expression of this trait in the fossil sample. Finally, the superior børders $\bullet$ AT-1500 and SDR-034 (R॰dríguez et al., 2003) have a V-shape contour, which is absent in AT-2000 and Kebara 2.

Thus, the single anatomical feature common to all the fossils is the presence of a marked anterior tubercle. In contrast, variation is present in the relief at muscular attachment sites, the morphølogy of the dorsal surface, and the contour of the superior border. These anatomical features alsø occur in modern human hyoid bodies (Fig. 2), althøugh usually at low frequencies. In the small sample of 17 modern human hyøids, one specimen (5.9\%) has a strong anterior tubercle (Fig. 2A), another individual (5.9\%) has a well-developed circular depression on the dorsal aspect (Fig. 2B), and two specimens (11.8\%) have a V-shaped superior border (Fig. 2C, D). This

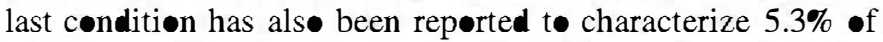
a larger sample of modern human hyøid bones (Papadopøulos et al., 1989). Finally, there is als- considerable variation in the degree $\bullet$ relief in the muscular insertion sites.

\section{Metric analysis}

The main metric dimensions in AT-1500 and AT-2000 are compared with Kebara 2, SDR-034, and a modern human sample in Table 2. The SH hyoids have very similar values in both the maximum medial height and the anteroposterior thickness, but AT-1500 has considerably larger values in the maximum ransverse diameter and the depth of the posterior surface. Nevertheless, in all measurements, the values in the tw• SH hyøid bones fall well inside the range of variation of $\bullet$ ur mødern human samples.

In comparison with Kebara 2, the SH hyøids have smaller values in the maximum medial height, maximum transverse diameter, and depth of the posterior surface. The SH fossils exceed Kebara 2 in the anteroposterior thickness but show similar values for the thickness of the inferior border. On the -ther hand, the values of maximum medial height and depth of the posterior surface in SDR-034 fall between those of the $\mathrm{SH}$ specimens. The $\mathrm{SH}$ hyoids have greater values than SDR-034 in the anteroposterior thickness and similar values in the thickness of the inferior border.

Figure 3 compares the maximum medial height and depth -f the posterior surface (which describe the shape of the bødy in lateral view) in the SH hyøids, the tw• Neandertal specimens, and our modern human sample with the data provided by Alemseged et al. (2006) for A. afarensis, African apes, and modern humans. The tw・ SH specimens, as well 


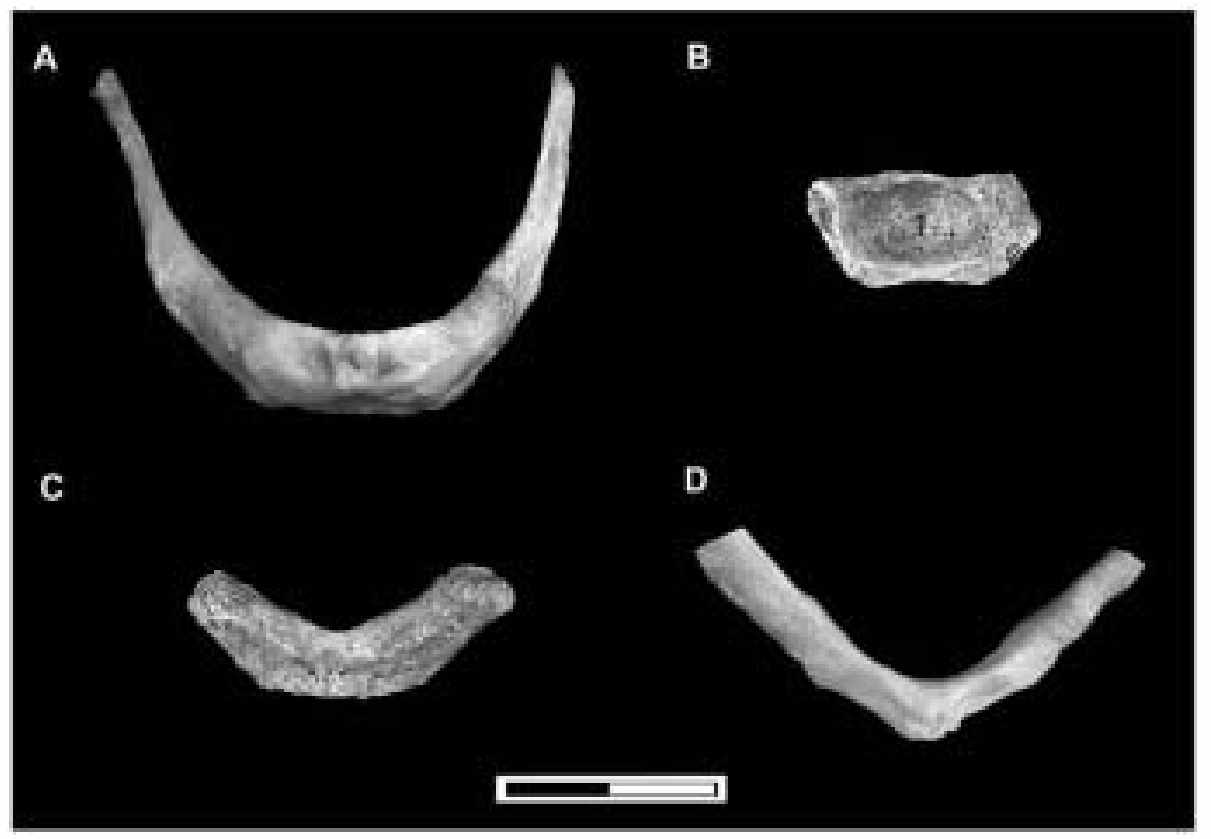

Fig. 2. Anatomical variation in modern human hyoid bones. (A) Ventral view showing a well-developed anterior tubercle (Individual 1 from cadaveric collection). (B) Dorsal view showing a well-delimited round fossa (Individual 197 from San Pablo). (C) Superior view showing a V-shaped superior contour (Individual 64 from San Pablo). (D) Superior view showing a V-shaped superior contour (Individual 1 from cadaveric collection). Scale bar $=2 \mathrm{~cm}$.

as the Neandertal hyoids, fall well inside the modern human distribution, and all of the Homo fossils are clearly different from $A$. afarensis and the African apes.

\section{Sexual dimorphism}

The range of variation among the SH fossils and the Neandertal specimens, in all the metric variables, is encompassed by that found to characterize living humans (Table 2), suggesting a degree of variation similar to that in $H$. sapiens. Sexual differences in hyoid-body dimensions have been identified in living populations, particularly in the maximum transverse diameter and the maximum medial height (Reed, 1993; Reesink et al., 1999; Kim et al., 2006; but see Miller et al., 1998), and the present study alsø føund significant differences $(p<\mathbf{0 0 1}$ ) between the male and female mean values (Table 2) in these variables.

When these twø variables are plotted against one an॰ther (Fig. 4), AT-2000 falls outside the male range of variation, suggesting a female attribution for this specimen, while AT-1500 falls in the region of overlap between the male and female distributions, making its sexual attribution unclear. Based on its associated pelvic anatomy, the Kebara 2 specimen has usually been considered male (Arensburg et al., 1985; Rak and Arensburg, 1987; Rosenberg, 1988; but see Tillier et al., 1989), and its hyoid dimensions clearly fall outside of the female range of variation (Fig. 3), suggesting a male attribution for this individual.

\section{Discussion}

The comparison between the SH, Neandertal, and modern human hyoids has revealed some interesting aspects.
Arensburg et al. (1989) reported that the depth of the posterior surface was the only measurement in the Kebara 2 Neandertal specimen that exceeded the range of variation of their modern human comparative samples. The present study has confirmed

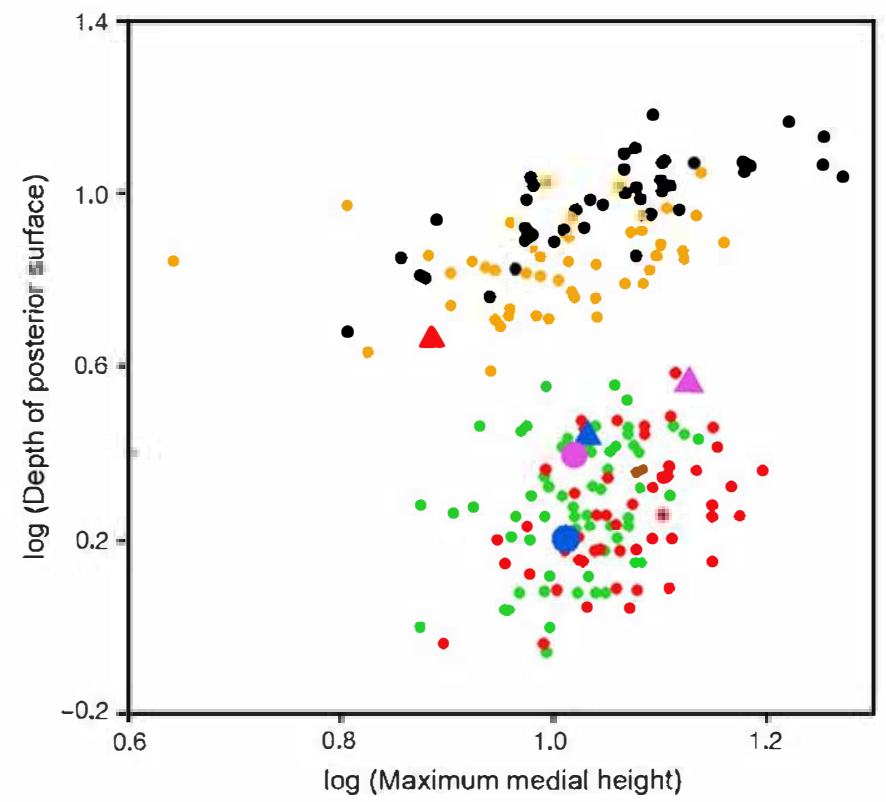

Fig. 3. Scatterplot comparing the values for logarithm of maximum medial height and logarithm of depth of posterior surface in the two SH specimens, Kebara 2, SDR-34, DIK-1-1, modern humans, chimpanzees, and gorillas. Gorilla gorilla, black circles; Pan troglodytes, orange circles; Homo sapiens, red and green circles; DIK-1-1, redriangle; AT-1500, blue riangle; AT-2000, blue circle; Kebara 2, magenta triangle; SDR-034, magenta circle. Data for $G$. gorilla, $P$. troglodytes, $H$. sapiens (green circles), and DIK-1-1 are from Alemsege et al. (206). Data for Kebara 2 and SDR-034 are from Arensburg et al. (1989) and Rodríguez et al. (203), respectively. Data for modern humans (red circles) are from present study. Adapted from Alemseged et al. (2006). 


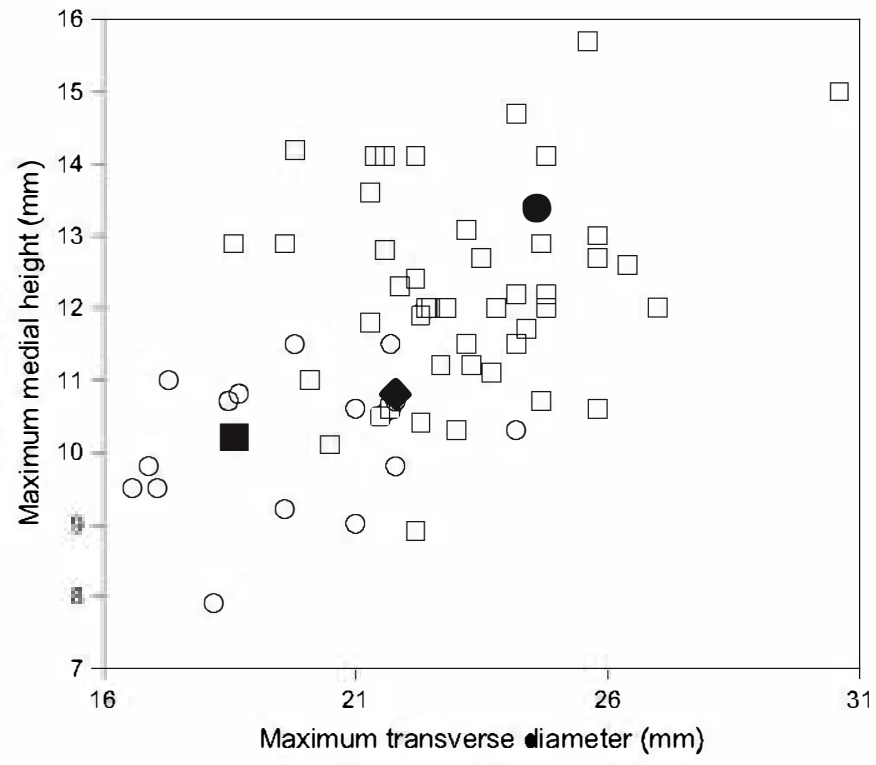

Fig. 4. Scatterplot comparing the values for the maximum wansverse diameter and maximum medial height in the SH specimens, Kebara 2, and the pooledsex modern human sample. Modern human males, open squares; modern human females, open circles; Kebara 2, solid circle; AT-1500, solid diamond; AT-200e, solid square. Data for Kebara 2 are from Arensburg et al. (1989).

this peculiarity in Kebara 2, whose depth of the posterior surface is greater than the other fossils and is almost 3 SD above the mean of our modern human sample, but is just within the upper limit of the range of variation. Nevertheless, the similarity in the values of the depth of the posterior surface in the $\mathrm{SH}$ specimens, SDR-034, and modern humans suggests that the condition in Kebara 2 is a particular feature of this specimen and should not be considered a Neandertal rait.

The anterøposterior thickness of the $\mathrm{SH}$ fossils is greater than that in both Neandertals, suggesting the possibility of a difference within the fossil sample. Nevertheless, these same differences exist between the modern human mean values in our sample (Table 2) and these of Arensburg et al. (1989) (5.13土 $0.97 \mathrm{~mm}$ ) and Rødríguez et al. (2003) (4.31 \pm 1.06$)$. Thus, the degree of variation found within the fossil sample is similar to that found in modern humans.

The thicknesses of the inferior borders of the $\mathrm{SH}$ and Neandertal specimens are very similar tø one another and are well below the modern human mean $(2.13 \pm 0.42)$ provided by Rødríguez et al. (2003). Interestingly, this feature seems to be independent of the overall size of the hyøid body (Rødriguez et al., 2003), and it may represent a distinctive feature shared by the fossil specimens. Finally, all the fossils show a strong anterior tubercle, a feature that seems to occur at lower frequencies in modern humans, at least in our small comparative sample.

Despite these minor differences, itis clear that the SH hyoids, as well as both Neandertal specimens, exhibit a human-like morphøløgy, clearly different from that found to characterize $A$. afarensis and the African apes. This finding suggests that modern human hyøid morphøløy is a very ancient feature of the genus Homo, one that was present in the last common ancestor of modern humans and Neandertals or perhaps even earlier.
Finally, we agree that the presence of a modern-human-like anatomy of the hyøid bone in a fossil specimen cannot be taken to demonstrate the existence of speech capacities (Lieberman et al., 1992). However, the presence in the SH fossils of a modern-human-like hyøid shows that some of the skeletal characteristics implicated in speech production in modern humans are very ancient features of the genus Homo. At the same time, the skeletal characteristics of the outer and middle ear associated with modern human auditory capacities and speech perception are als present in the SH hominins (Martínez et al., 2004).

\section{Conclusions}

The morphological and metric variation found in the $\mathrm{SH}$ and Neandertal specimens is of the same magnitude as that found to characterize living humans. Relying on modern human patterns and the evidence from the adult male Kebara 2 Neandertal hyoid, the $\mathrm{SH}$ fossils represent late adolescent or adult individuals, and AT-2000 is suggested to belong to a female individual. The SH fossils share with the Neandertals a high frequency of a strong anterior tubercle and a thin inferior border of the hyøid body, and they differ in the anterøposterior thickness of the body.

The hyøid bones recovered from the Sima le los Huesos represent the $\bullet$ ldest fossil evidence for the anatømy of this bone in the genus Homo. Their morphøløgy is modern-human-like and very different from that described for the African apes and $A$. afarensis (Alemseged et al., 2006). Thus, the genus Homo has been characterized by a modern-human-like anatomy of the hyoid bone since at least $530 \mathrm{ka}$. New discoveries of fossil hyøid bones will shed new light on the evolution of this bone in the human lineage and make it possible to contrast and refine the hypotheses presented here.

\section{Acknowledgements}

We thank the Atapuerca Research and Excavation Team for their work in the field, especially A. Esquivel, N. García, C. Lorenze, and A. Bønmatí for their work at the Sima de los Hueses site. We als thank Y. Rak, wh॰ kindly provided access the thiginal specimen Kebara 2; B. Latimer and L. Jellema kindly gave us access to the Hamann-Tødd Osteøløical Cøllection housed at The Cleveland Museum of Natural History (USA) and O. Martín measured the Hamann-Toddhyøid bones. C. Cavada and A. Olaya kindly provided hyoid bones derived from a cadeveric collection in the Dpt• de Morføløía de la Facultad de Medicina de la Universidad Autónoma de Madrid. R. Quam and A. Gracia have enjoyed the support of a grant from the Fundación Duques de Soria/Fundación Atapuerca. L. Rødríguez is funded by a grant from Fundación Siglø para las artes de Castilla y León. The excavations at the Atapuerca sites are funded by the Junta de Castilla y León. This research was supported by the Ministeri॰ de Ciencia y Tecnøløgia of the

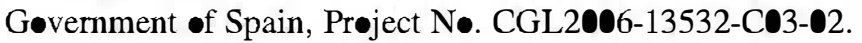




\section{References}

Adán-Álvarez, G.E., 2003. Memoria de la actuación arqueológica en el antiguo monasterio de San Pablo, Burgos. Junta de Castilla y León, Valladolid.

Aiello, L., Dean, M.C., 199. An Introduction to Human Evolutionary Anatomy. Academic Press, London.

Alemseged, Z., Spoor, F., Kimbel, W.H., Bobe, R., Geraads, D., Reed, D., Wynn, J.G., 2006. A juvenile early hominin skeleton from Dikika, Ethiopia. Nature 443, 296-31.

Arensburg, B., 1991. The Vertebral Column, Thoracic Cage and Hyoid Bone. Ir: Bar Yosef, O., Vandenneersch, B. (Eds.), Le Squeletre Moustérien de Kébara 2. Cahiers de Paléoantbropologie. Édirions du CNRS, Paris, France, pp. 113-146.

Arensburg, B., Bar-Yosef, O., Chech, M., Goldberg, P., Laville, H., Meignen, L., Rak, Y., Tchernov, E., Tillier, A.M., Vandenneersch, B., 1985. Une sépulture néandertalienne dans la grotte de Kébara (Israël). C.R. Acad. Sci. Paris 300 , $227-230$.

Arensburg, B., Schepartz, L.A., Tillier, M.A., Vandenneersch, B., Rak, Y., 199. A reappraisal of the anatomical basis for speech in Middle Paleolitbic hominids. Am. J. Phys. Antbropol. 83, 137-146.

Arensburg, B., Tillier, A.M., Vandenneersch, B., Duday, H., Schepartz, L.A., Rak, Y., 1989. A Middle Palaeolitbic human hyoid bone. Nature 338, 758-760.

Arsuaga, J.L., Marinez, I., Gracia, A., Carretero, J.M., Carbonell, E., 1993. Three new human skulls from the Sima de los Huesos middle Pleistocene site in Siena de Atapuerca, Spain. Nature 362, 534-536.

Arsuaga, J.L., Martínez, I., Gracia, A., Carretero, J.M., Lorenzo, C., García, N., Ortega, A.1., 1997a. Sima de los Huesos (Sierra de Atapuerca, Spain). The site. J. Hum. Evol. 33, 109-128.

Arsuaga, J.L., Martínez, I., Gracia, A., Lorenzo, C., 1997b. The Sima de los Huesos crania (Sierra de Atapuerca, Spain). A comparative study. J. Hum. Evol. 33, 219-282.

Bennúdez de Castro, J.M., Arsuagan J.L., Carbonell, E., Rosas, A., Marinez, I., Mosquera, M., 1997. A hominid from the lower Pleistocene of Atapuerca, Spain: possible ancestor to Neandertals and modern humans. Science 276, 1392-1395.

Bernúdez de Castro, J.M., Martinón-Torres, M., Lozano, M., Sarmiento, S., Muela, A., 2004. Paleodemography of the Atapuerca-Sima le los Huesos hominin sample: A revision and new approaches to the paleodemography of the European middle Pleistocene population. J. Anthropol. Res. 61, 5-26.

Bischoff, J., Williams, R, Rosenbauer, R., Aranburu, A., Arsuaga, J., García, N., Cuenca, G., 2007. High-resolution U-series dates from the Sima de los Huesos yields $60+\infty-66$ kyrs: Implications for the evolution of the Neanderthal lineage. J. Archaeol. Sci. 34, 763-770.

Carbonell, E., Bennúdez de Castro, J.M., Arsuaga, J.L., Díez, J.L., CuencaBescós, G., Sala, R., Mosquera, M., Rodríguez, X.P., 1995. Lower Pleistocene hominids and artifacts from Atapuerca TD6 (Spain). Science 269, 826-830.
Kim, D.I., Lee, U.Y., Park, D.K., Kim, Y.S., Han, K.H., Kim, K.H., Han, S.H., 2006. Morphometrics of the hyoid bone for human sex determination from digital photographs. J. Forensic Sci. 51, 979-984.

Liebernnan, P., Laitman, J.T., Reidenberg, J.S., Gannon, P.J., 1992. The anatomy, physiology, acoustics and perception of speech: essential elements in analysis of the evolution of human speech. J. Hum. Evol. 23, 447-467.

Martínez, I., Arsuaga, J.L., 1997. The temporal bones from Sima de los Huesos middle Pleistocene site (Sierra de Atapuerca, Spain). A phylogenetic approach. J. Hum. Evol. 33, 283-318.

Martínez, I., Rosa, M., Arsuaga, J.L., Jarabo, P., Quam, R., Lorenzo, C., Gracia, A., Carretero, J.M., Bermúdez de Castro, J., Carbonell, E., 2004. Auditory capacities in middle Pleistocene humans from the Sierra de Atapuerca in Spain. Proc. Natl. Acad. Sci. U.S.A. 101, 9976-9981.

Miller, K.W.P., Walker, P.L., O'Halloran, R.L., 1998. Age and sex-related variation in hyoid bone morphology. J. Forensic Sci. 43, 1138-1143.

Nishimura, T., Mikami, A., Suzuki, J., Matsuzawa, J., 2006. Descent of the hyoid in chimpanzees: Evolution of face flattening and speech. J. Hum. Evol. 51, 244-254.

O'Halloran, R.L., Lundy, J.K., 1987. Age and ossification of the hyoid bone: forensic implications. J. Forensic Sci. 32, 1655-1659.

Papadopoulos, N., Lykaki-Anastopoulou, G., Alvanidou, E.L., 1989. The shape and size of the human hyoid bone and a proposal for an alternative classification. J. Anat. 163, 249-260.

Rak, Y., Arensburg, B., 1987. Kebara 2 Neandertal pelvis: First look at a complete inlet. Am. J. Phys. Antbropol. 73, 227-231.

Reed, M.H., 1993. Ossification of the hyoid bone during childhood. Can. Assoc. Radiol. J. 44, 273-276.

Reesink, E.M., Van Immerseel, A.A.H., Brand, R., Bruintjes, T.J.D., 1999. Sexual dimorphism of the hyoid bone? Int. J. Osteoarchaeol 9, 357-360.

Rodríguez, L., Cabo, L.L., Egocheaga, J.E., 2003. Breve nota sobre el hioides Neandertalense de Sidrón (Piloña, Asturias). In: Aluja, M.P., Malgosa, A., Nogués, R.M. (Eds.), Antropología y Diversidad, vol. 1. Edicions Bellaterra, Barcelona, Spain, pp. 484-493.

Rosas, A., Martínez-Maza, C., Bastir, M., García-Tabernero, A., LaluezaFox, C., Huguet, R., Ortiz, J.E., Julià, R., Soler, V., Torres, T., Martínez, E., Cañaveras, J.C., Sánchez-Moral, S., Cuezva, S., Lario, J., Santamaría, D., De la Rasilla, M., Fortea, J., 2006. Paleobiology and comparative moıphology of a late Neandertal sample from El Sidrón, Asturias, Spain. Proc. Natl. Acad. Sci. U.S.A. 103, 19266-19271.

Rosenberg, K., 1988. The functional significance of Neandertal pubic length. Curr. Anthropol. 29, 595-617.

Shimizu, Y., Kanetaka, H., Kim, Y.11., Okayama, K., Kano, M., Kikuchi, M., 2005. Age-relate morphological changes in the human hyoid bone. Cells Tissues Organs 180, 185-192.

Tillier, A.M., Arensburg, B., Duday, H., 1989. La mandibule et les dents du Neánderthalien de Kébara (Homo 2), Mont Carmel, Israël. Paleorient 15, 39-58. 